\title{
POLICY AND IMPLEMENTATION OF EDUCATION MANAGEMENT BASED ON MADRASAH
}

\author{
Nana Meily Nurdiansyah ${ }^{1}$, Hudriyah ${ }^{2}$ \\ ${ }^{1}$ Islamic Education Guidance and Counseling Department, Institut Daarul Qur'an, \\ Banten, Indonesia \\ ${ }^{2}$ Arabic Language Education Department, Universitas Islam Negeri Maulana Malik Ibrahim, \\ Malang, East Java, Indonesia \\ Email: nana.meily@uinjkt.ac.id ${ }^{1}$, uuthudriyah143@gmail.com²
}

\begin{tabular}{l|l|l} 
Received: September 2020 & Accepted: March 2021 & Published: March 2021
\end{tabular}

\begin{abstract}
:
This study aims to analyze policies from the socio-political scope as the basis for development in education in madrasah. Therefore, it goes on to say that this research was conducted through a descriptive qualitative approach to the type of library research, with the data source referring to literature data. The data analysis technique was carried out using content analysis, the scope of which consists of the depth of information content. The results showed that madrasah-based management is participatory management of madrasah by involving the principal, teachers, students, stakeholders, and the community to achieve the quality of education goals. The movement of education reform from centralization to decentralization abroad has been going on for 30 years, since 1960-1990. In Indonesia, constitutional reformation of education began to coincide with the reform era marked by the fall of the New Order in 1998. Education, which had been the matter of the central government, since the enactment of regional autonomy through Law number 22 of 1999 concerning Regional Government, was later amended by Law number 32 of the year. 2004, then the education affairs were handed over to the local government.
\end{abstract}

Keywords: Management Policy, Education, Madrasah

\begin{abstract}
Abstrak:
Penelitian ini bertujuan menganalisis kebijakan dari scope social-politik sebagai dasar pengembangan dalam pendidikan di Madrasah. Oleh karenanya, lanjut dikatakan bahwa penelitian ini dilakukan melalui pendekatan kualitatif deskriptif jenis library research, dengan sumber data merujuk pada data literature. Teknik analisis data dilakukan menggunakan content analysis yang cakupannya terdiri dari kedalaman suatu isi informasi. Hasil penelitian menunjukkan bahwa manajemen berbasis madrasah adalah pengelolaan madrasah yang bersifat partisipatif dengan melibatkan kepala sekolah, guru, murid, stake holder dan masyarakat untuk mencapai tujuan pendidikan yang bermutu. Pergerakan reformasi pendidikan dari sentralisasi menuju desentralisasi di luar negeri sudah berjalan 30 tahunan, sejak 1960-1990. Di Indonesia reformasi pendidikan secara konstitusional mulai dilakukan bersamaan dengan era reformasi yang ditandai atas kejatuhan orde baru tahun 1998. Pendidikan yang tadinya menjadi urusan pemerintah pusat, sejak diberlakukannya otonomi daerah melalui UU nomor 22 tahun 1999 tentang Pemerintah Daerah, kemudian diubah dengan UU nomor 32 tahun 2004, maka urusan pendidikan diserahkan kepada pemerintah daerah.
\end{abstract}

Kata Kunci: Kebijakan Manajemen, Pendidikan, Madrasah 


\section{INTRODUCTION}

The development of science and technology has an impact on human life. This impact is in the form of various and increasing demands for life needs. The diversity of these demands accelerates the fulfillment of qualified human resources to adapt to these changes. Each aspect of life influences one another. The economic aspect affects politics, politics affects education, education affects culture, and so forth. These changes continue to take place so that there is a postulate "nothing lasts but change itself". We often know that the 21st century is predicted to be the age of technology and information so that whoever controls it will lead the world. I hope that this prediction will now come true. This is evidenced by the rapid development of technology that facilitates all human affairs. These changes certainly have a significant impact on the world of education. The world of education as an agent of transformation is required to prepare humans to survive in their nature and in their time (Naisabit, 1982), and then now industrial technology 4.0 or later will be reborn with the terms used.

Discoveries in the world of science and technology, such as in the fields of management, psychology, information technology, have a direct effect on the substance, methods, and governance of education. When the world of education is not agile in responding to the rapid changes in the global society, several assumptions emerge. There is an assumption that learning methods need to be addressed first following discoveries in psychology and information technology. When changes are made through learning approaches and methodologies it turns out that the changes have not met expectations, then other assumptions emerge. This assumption is that there is a need for changes in the education governance system.

Along with the development of the application of democratization in various lines of community life, including in the corporate world, and the application of democratic principles has been successful, education should also be managed by democratic principles, where every element contained in educational organizations is directly involved in the process of implementation. education. Because education can change the order of people's lives for the better and quality education is relevant to various needs (Eslianna, Lian, \& Sari, 2020).

So far, what determines education policy is controlled by a top-down bureaucracy. So when the principles of democracy are applied in the implementation of education, education management is down top, where the principal, teachers, staff, parents of students, and the community are directly involved in the process of program formulation, curriculum, program implementation, funding, monitoring, and evaluation. This management model has various terms, but the substance is the same. Some call it school base management, school effectiveness, site-based management, school management, and so on. In Indonesia, it is known as School / Madrasah Based Management. 
The community-based school management model is like an "ice ball" rolling to various corners of the world, including Indonesia. It's just that with the slow pace of political change, the implementation of School / Madrasah Based Management (MBS/M) has begun to roll out since the Reformation Order. The push for reform in the world of education has been so strong from the community but has not found the right momentum. After the enactment of Law number 20 of 1998 concerning Regional Government which mandates the implementation of Regional Autonomy, the implementation of school / madrasah-based management has only been initiated in several cities. With the birth of Law number 20 of 2003 concerning the National Education System, the implementation of school / madrasah-based management in Indonesia is mandatory due to regulatory demands (Law and Government Regulation of the Republic of Indonesia on Education, 2006).

Referring to the above background, if it is analyzed with various considerations, the birth of policies on educational institutions cannot be avoided from the realm of economic value, such as buying and selling power and profit and loss (Ahmed, 2008), then reliable education management is in a governance framework which is part of of the institutional management system process, of course, includes; first, justice and equality; second, high quality and relevant; third, professionalism is rich and not dry; fourth, openness, empowerment, participation, and excellence (Gaffar, 2000). At least to realize this challenge, it needs to be studied and analyzed in depth within the framework of the policy and implementation of school / madrasah Based Education Management.

Previous research has emphasized the implementation and quality of management alone as stated by some of the researchers above. This research has been done a lot, but there is still room that needs to be studied specifically and comprehensively, therefore the novelty of this research focuses on aspects of socio-political policy analysis in the scope of education in madrasah.

\section{RESEARCH METHODS}

In this study, researchers used a descriptive qualitative approach to the type of library research, which is based on a collection of data in the form of writing (books, national and international journals, and mass media) or scientific works (theses, and dissertations) as relevant sources and research objects based on literature. based on the realm of policy and management. Besides, qualitative research will serve as a provision to be able to understand the social context more broadly and deeply (Sugiyono, 2016). The data collection technique was carried out based on literature data (Arikunto, 1998). And the data analysis technique is done through content analysis whose scope consists of the depth of information content. Furthermore, this content analysis presents three requirements including; objectivity, systematic approach, and generalization (Muhadjir, 2000). The three requirements are intended to reflect an accurate and accountable data order so that findings and results are obtained with a good level of validity related to the policy and implementation of the intended management. 


\section{RESULTS AND DISCUSSION}

\section{Development of Madrasah Based Management Abroad (Socio-Political)}

The issue of school management autonomy or SBM has been popular since the 1990s. School-based management was inspired by the education model of the United States, then several countries implemented school-based management which was very effective in improving schools such as England, Australia, New Zealand, Spain, Canada, Brazil, El Salvador, Hong Kong, China, Uganda, Thailand, Argentina, Mexico, Qatar, Kenya, Iran, Senegal, and Indonesia ( $\mathrm{Ng} \& \mathrm{Chan}, 2008$; Lee \& Chiu, 2017). Even though we have a long history. In 1887 teachers in New York formed associations for the common good. Likewise in Chicago, an association of teachers led by Margarette Harley was founded. In 1903 teachers in Philadelphia formed a teacher association known as the Philadelphia Teacher Association. Through this association, teachers strive to increase their dignity and income. In 1957 the National Education Association in America was formed, which functions as a forum for professional teacher associations.

In Atlanta, too, teachers formed associations to deal with City Council pressure. Another teacher movement also emerged, spearheaded by the socialist Henry Lin Ville, John Dewey, and Suffrajist Charlotte Perkin Gilman. They form associations in addition to economic goals, as well as preach the role of teachers in determining school policy and can obtain representatives at education stages in New York, participate in helping with school matters, clean up politics and deviant decisions in the United States and increase freedom of discussion public in educational matters.

The journey of the education reform movement intensively ran from the 1960s to the 1990s. This movement led to the decentralization of education in the form of school site management or school base management (Danim, 2010). According to Wirt (2005), there are two types of educational reforms: First, Managerial Decentralization, where the central educational authority determines certain tasks carried out by school principals and teachers in the school environment. In this type, the center gives up limited authority to the bottom, local schools are still responsible for the center. Second, Local-Based Management, which is a structure that gives authority to parents, teachers, and school principals to determine priorities, allocate budgets, determine curricula, pay, and lay off staff. The decision-making authority lies at the local level and the responsibility does not go to the center, but the community (Danim, 2010).

Apart from America, educational reform has also occurred in the Asia Pacific, such as Australia, New Zealand, Mainland China, Singapore, Malaysia, and Hong Kong. The change is looking for an effective form of school-based management to ensure the quality of education and curriculum changes.

\section{Development of Madrasah Based Management in Indonesia (Socio-Political)}

The push for educational reform has long been rolling through the writings of intellectual leaders in Indonesia. but the reforms have not yet found momentum. When the World Bank issued the famous report "The East Asian Miracle" in 1991 which classified Indonesia as an Asian tiger, the Indonesian people were quite proud. but after the economic crisis that hit the world. A 1994 
report by Paul Krugman, a professor of economics from MIT, stated that Asian economic growth is pseudo growth, the result of a perspective, not inspiration, making the Indonesian people aware that the economic foundations are not strong and Indonesia is inseparable from global changes (Tilaar, 2002).

The occurrence of the economic crisis triggered the collapse of the New Order power and the birth of the Reformation Order. The fall of the new order, undermining the values of the autocracy built by the new order. The new order began, democracy rolled, the people began to understand and recognize the freedom of individuals who were responsible, where these rights were taken away during the New Order era (Tilaar, 2002).

With the collapse of the New Order, the Indonesian people reorganized the life of the nation and state towards a civil society, where people were free and had the responsibility to develop their society. Civil society is characterized by mutual respect for differences, a life of tolerance, respect for opinions, and obedience to collective decisions. Such a society needs a clean government, serves, and is free from corruption. To support the realization of this civil society, it is necessary to reform the values and legislation. One manifestation of the implementation of this democracy is to give the regions the authority to regulate themselves through regional autonomy.

This autonomy regulation also has implications for education, because most of the affairs of the central government are left to the regions, except for defense and security, justice, finance, foreign affairs, and religious affairs. Education affairs in the reform era were handed over to local governments. The handover of education affairs is not without obstacles, because there are still tensions between the central and regional governments.

The enactment of the regional autonomy law, madrasah-based education management, is gaining momentum. The management of education management is given to schools, while the central government only sets education standards. Through Government Regulation number 19 of 2006, the government establishes National Education Standards covering content standards, graduation competency standards, process standards, teachers and education staff standards, facilities and infrastructure standards, management standards, and assessment standards. Schools and communities compose their curricula according to the specifics of their respective regions but refer to the National Education Standards made by the central government.

The madrasah-based management model that Indonesia used initially was School-Based Quality Improvement Management (MPMBS). When the MPMBS policy was issued, since 1999-2003 the number of junior high schools implementing pilot increases. In 1999 there were 191 schools, in 2000 there were 326 schools, in 2001 there were 929 schools. And in 2003 there were 3,063 schools (Danim, 2010).

Why does Indonesia use this model? According to Kholis (2005), there are at least three reasons: First, schools know more about their strengths, weaknesses, opportunities, and threats, so that schools optimize the use of available resources. Second, schools know their needs better. Third, school members and the community can create healthy transparency and democracy. 
The birth of Law number 20 of 2003 concerning the National Education System, provided fresh air for the Indonesian people to become quality human resources, who can survive and compete during international political economy struggles under the Law. Therefore, as a manifestation, it is necessary to show it through the educational design in the implementation of SBM / M, which gains legitimacy. This law emphasizes that the community has the right to participate in implementing education including development, curriculum implementation, and obtaining funding from the government, as in article 55, among others: (1) the community has the right to organize community-based education in formal and non-formal education by the peculiarities of religion and the social environment. and culture for the benefit of society. (2) the implementation of community-based education develops and implements a curriculum and evaluation of education, as well as its management and funding by national education standards. (3) The funds for the provision of communitybased education may come from the organizers, the community, the government, regional governments, and/or other sources that do not conflict with the prevailing laws and regulations. (4) community-based educational institutions can obtain technical assistance, subsidized funds, and other resources fairly and equitably from the government and/or regional governments. (5) provisions regarding community participation as referred to in paragraphs (1), paragraph (2) and paragraph (4) shall be further regulated by government regulations (Dirjenpendis, 2006).

Technically, the implementation of madrasah Based Management in Indonesia, in this case, the Ministry of National Education, now the Ministry of Education and Culture, along with the Local Government with the assistance of The United Nation Children's Fund (UNICEF), United Nation Educational Scientific and Cultural Organization (UNESCO), since 1999 in seven (7) districts in four (4) provinces. After being declared successful in several piloting schools, the MBS program received donors from within and outside the country, including Nzaid, AusAID, USAID, Plan International, City Bank, Save The Children, Jica, and Kartika Soekarno Foundation. The implementation of the School / Madrasah Based Management program in Indonesia was evaluated in 2000, 2002, 2005, and 2010. The results of the evaluation in 2000, 2002, 2005 indicated that the MBS / M development program had positive impacts, including (1) Improving School Management which is more transparent, participatory, democratic, and accountable; (2) Improving the Quality of Education; (3) Decreased dropout rates; (4) Increasing the implementation of student-centered learning with active, creative, effective, and fun learning strategies; and (5) Increasing community participation in primary school education.

In 2010 the creating learning communities for children (CLCC) conducted monitoring and evaluation of the implementation of SBM / $\mathrm{M}$ in Indonesia. The results of monitoring and evaluation included: (1) The SBM / M team varied in each region (background of personnel, ownership of work programs, and solidarity in collaboration); (2) Regional participation in providing funds for the implementation of SBM varies, ranging from billions of 
rupiah to no allocation at all; (3) school clusters have a clear organizational structure, tasks and functions are well planned and carry out work programs routinely; (4) SBM in schools which are used as a pilot project, is implemented $95 \%$ at the school level, $91 \%$ of school principals, $80 \%$ of teachers and $35 \%$ of school committee members; (5) Concerning School Management, the majority of schools have a vision and mission formulation that school committee members can understand, have a school plan and have a high percentage of implementing the plan (Sholekah \& Mahmudah, 2020).

\section{Management Elements}

The keyword for implementing SBM / $M$ is the existence of participatory self-management of schools or madrasah, involving school principals, teachers, students, stakeholders, and the community to achieve quality education goals (Umar, Krauss, Samah, \& Hamid, 2017). While the reasons and objectives for implementing SBM / M according to the World Bank (1998), there are several reasons for applying SBM, including economic, political, professional reasons, administrative efficiency, financial, student achievement, accountability, and school effectiveness. Then, the Directorate General of Primary and Secondary Education further said that SBM aims to make schools independent and empower them by giving them authority, flexibility, and resources to improve the quality of schools (Bafadal, 2009).

Quality education certainly has a reflection of management that cannot be separated from various elements of management. George R. Terry (2005) states that basic elements are available resources to achieve goals in management, namely: (a) Men; (b) Money; (c) Machines; (d) Method; (e) Materials. Apart from the five elements above, there is the sixth element of management, namely, "Market" (Rozalinda, 2014; Amir, 2015; Rofiq, 2017; Tardian, 2019). These management elements are usually known as "6 M's" in Management (The Six M's in Management) as can be seen in the figure below.

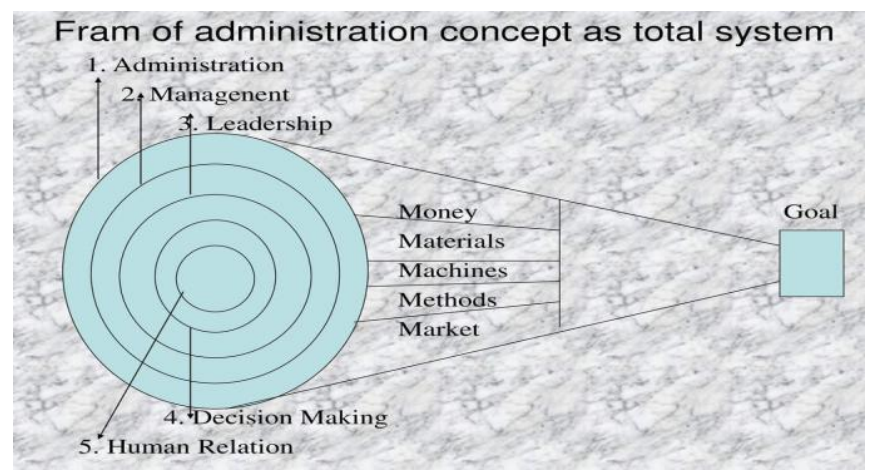

Figure 1 : Chart of the Six Elements of Management

Figure 1 shows that humans are the main elements and means to achieve predetermined goals. The paradigm of opening up to the market results in continuous improvement, through critical thinking and evaluation of the market's will and expectations so that they can find educational products needed by society-people (Capel, 2012). 
Why are important management elements discussed in discussing SBM / M? This is because the function of management, in general, is to move these elements to achieve goals. School as an organization cannot be separated from the concept of management, therefore these six elements (men, money, machine, methods, material, and market) must be present in school.

\section{Principles of Madrasah Based Management}

Law Number 20 of 2003 concerning the National Education System in Article 48 paragraph (1) states that the management of education funds is based on the principles of justice, efficiency, transparency, and public accountability. In line with this mandate, Government Regulation Number 32 of 2013 concerning Amendment to Government Regulation Number 19 of 2005 concerning National Education Standards Article 49 paragraph (1) states that the management of education units at the primary and secondary education levels implements school-based management shown by independence, partnership, participation, openness, and accountability.

Based on the contents of the policy above, there are principles of SBM which are contained in seven items which are abbreviated as K4 PEA including: first, Independence. The school's authority to manage resources and regulate the interests of school residents based on aspirations that are in line with laws and regulations; second, Justice. Schools do not take sides with any of the human resources involved in managing school resources and in the distribution of resources for the benefit of improving school quality; third, openness. Management in the context of SBM is carried out transparently so that all school members and stakeholders can know the mechanisms for managing school resources; fourth, Partnership. Collaboration between schools and communities, both individuals, groups/organizations, as well as the business world, and the industrial world; fifth, Participative. The participation of all stakeholders related to the school in managing schools and making decisions. Their participation can be done through formal procedures. The form of participation can be in the form of donations of manpower, funds, and infrastructure, as well as technical assistance in the context of school development; sixth, efficiency. Efficiency also means saving on the use of resources while still achieving the target of improving the quality of schools; and seventh, accountability. Emphasizes the responsibility for the implementation of education in schools, especially the achievement of the target of improving the quality of the school. Schools in managing resources are based on laws and regulations and can be accountable to the government, all school members, and other stakeholders. Responsibilities include; implementation of school management processes and components. Accountability can be made in writing and unwritten accompanied by valid administrative evidence and physical evidence (buildings, benches, and laboratory equipment) (Myende, Samuel, \& Pillay, 2018).

Furthermore, in addition to the seven main principles above, according to Nana Meily Nurdiansyah (2020), these principles should be outlined and understood, and obeyed by members of the madrasa, including teachers and 
leaders, and their staff. Among the principles referred to are first, the principle of orderly administration; second, the principle of mental attitude education; third, work ethic principles which are based on the soul and philosophy of life (character building); fourth, the principle of the ethos of independence in togetherness (Arief \& Lubis, 2020).

\section{Implementation of Madrasah Based Management}

Talking about implementation, of course, it will have an impact on a reference management practice that is held, there are at least three criteria that underlie this implementation, namely; Strategy, operational steps, and implementation indicators.

First, the madrasah based management implementation strategy. In implementing it, it is necessary to prepare the potentials that exist in school institutions, because in the end, these potentials will be encouraged and developed. According to Hit, Irelan, and Hoskisson, as quoted by Siahaan, these potentials, there are two resources, tangible and intangible resources. Tangible resources are activities that can be seen, touched, and calculated. Meanwhile, intangible resources such as intellectual property, patents, trademarks, networks, organizational culture, reputation, and interactions with people (Siahaan, 2006). The strategies that need to be prepared are: 1) Preparing madrasah human resources. Before implementing madrasah-based management, the first thing is to prepare a mindset (action pattern), heart set (heart pattern), and action set (action pattern). The new management pattern demands that school members change from pro-establishment to pro-change. For this reason, it is necessary to prepare adequate human resources who are willing to change, practice, and increase their potential;2) Preparing managerial conceptually and implement timely. It is intended that a complete understanding of the new managerial pattern of education is needed. Schools have to prepare themselves transparently in preparing school programs, which were previously only compiled by a handful of people. The new management implementation pattern involves all elements in schools. Here's a new managerial pattern.

\begin{tabular}{|l|l|l|}
\hline \multicolumn{1}{|c|}{ Old Pattem } & Transformation & \multicolumn{1}{c|}{ New Pattern } \\
\hline Subordination & \multicolumn{2}{|l|}{ Autonomy } \\
\hline Decision-Making & & Decision-Making \\
\hline Centralized & & Participative \\
\hline Rigid Motion Space & & Flexible Space \\
\hline Bureaucratic Approach & & Professional Approach \\
\hline Centralistic & & Decentralistic \\
\hline Regulated & & Self-motivation \\
\hline Over Regulation & \multirow{2}{*}{ Towards } & Deregulation \\
\hline Control & & Influence \\
\hline Directing & Facilitate \\
\hline Avoiding Risks & Manage Risk \\
\hline Use Everyone's Money & & Use Money Efficiently \\
\hline Intelligent Individual & & Smart Teamwork \\
\hline Personal Information & & Information Shared \\
\hline Delegation & & Empowerment \\
\hline Hierarchical Organization & & Flat Organization \\
\hline
\end{tabular}

Figure 2 : New Managerial Patterns 
Referring to the Figure 2 is a form of an effort to revitalize classic and contemporary management, with various developments in the aspects of policy and implementation that are developing in Indonesia so that it can provide an ideal concept map for future education; 3) Preparing for community involvement through the madrasah committee. This is a keyword for the implementation of Madrasah Based Management, therefore it is necessary to identify the elements of society that will be involved in the madrasah committee. This identification includes, who, why, and how the form of involvement.

The school/madrasah committee functions include; (a) encourage the growth of public attention and commitment to quality education; (b) collaborating with the community (individuals/organizations/business world/industry) and the government about quality education; (c) accommodate and analyze the aspirations, ideas, demands and various educational needs put forward by the community; (d) provide input, considerations, and recommendations to educational units; (e) encourage parents and the community to participate in education to support the improvement of the quality and equity of education; (f) raising public funds in the framework of financing the implementation of education in education units, and; ( $\mathrm{g}$ ) evaluating and supervising educational program policies, delivery and outputs (Ministry of Education and Culture, 2004).

Second, the Operational Steps for the Implementation of the Curriculum can be done in various ways, such as; 1) Implementing the socialization of school/madrasah-based management. School is a system consisting of interrelated elements and therefore the results of educational activities in schools are the collective result of all school elements. With this kind of thinking, all school elements must understand the concept of school/madrasahbased management (what, why, and how); 2) Increase the number of school partners both from inside and outside the school. Partnerships within schools include, among others: principals and teachers, teachers with teachers, teachers with students, students with students, and so on. The school's partnerships with the surrounding community include, among others: the principal and the school committee, the teacher and the parents of the students, the principal and the head of the district/city education office, and so on; 3) Reformulating school rules, the role of school elements, the habit of relationships between school elements. The shift from centralized (centralized) management to school-based management requires revisiting. School rules need to be reformulated to fit the demands of school / madrasah-based management, namely autonomy, flexibility, and participation. Likewise, the role of each school element needs to be reviewed by the above demands, namely school democratization; 4) Applying the principles of good governance. These principles include participation, transparency, responsibility, accountability, forward-looking, law enforcement, justice, democracy, predictability, sensitivity, professionalism, effectiveness, efficiency, and legal assurance. Schools strive to implement them in various ways, such as: making school rules or guidelines on procedures for implementing the principles of good governance, providing facilities to facilitate the implementation of good governance principles, conducting 
advocacy, publication, relations with stakeholders, and so on. Which is tailored to the context of the needs, characteristics and abilities of each school; 5) Clarify the functions and aspects of management of the institution. Education management in general and madrasah management, in particular, are institutional management carried out with and through educators and education personnel to achieve their goals effectively and efficiently.

Two things are at the core of madrasah management, namely the management function and madrasah affairs. Management functions include planning, organizing, implementing, coordinating, and supervising or controlling. Madrasa affairs include curriculum, teaching and learning process, education and education personnel, facilities and infrastructure, student affairs, finance, assessment, institutional relations with the community, environmental education (Adiwiyata program), drug control, and so on; 6) Increase the capacity of the madrasah. The capacity building (capability and capability) of the madrasah is carried out through various efforts, for example: (a) providing guidelines for the concept of MBM, implementation, evaluation. (b) training, workshops, focus group discussions, seminars, and lessons learned by madrasah that have successfully implemented MBM and so on; 7) Redistribute Finance and Responsibilities. In the centralistic era, authority and responsibility in managing madrasas accumulated on the head of the madrasah (one-man show). Everything depends on the educational institution as if the head of the madrasa was like a king.

In MBM, democracy is the soul. Therefore, authority and responsibility are no longer solely focused on the head of the madrasah but are distributed or distributed to stakeholders, madrasah education. In this way, power in the madrasah is no longer solely on the shoulders of the head of the madrasah but is distributed to all madrasah stakeholders. So, power shifts from one person (head of the madrasah) to collective strength. Therefore, madrasah needs to have teamwork that is compact, intelligent, and dynamic; 8) Prepare a madrasah development plan (RPM/RKM), implement and monitor and evaluate it. In practice, madrasah are expected to design, implement and evaluate RPM, RKM on an ongoing basis every 5 years (strategic plans) and annual plans. The results of the evaluation should be used as input to improve the design of the RPM, RKSM, and its implementation (Anonim, 2013).

Third, MBM Implementation Indicators. To assess whether a madrasah has been implemented or not, it can be measured through the following indicators: (a) community participation is facilitated through the madrasah committee; (b) transparency of madrasah management (program and budget); (c) realistic madrasah needs assessment program; (d) understanding of stakeholders regarding the vision and mission of madrasah; (e) the physical environment of the madrasah is comfortable, well-maintained; (f) conducive madrasah climate; (g) quality-oriented, creating a quality culture; (h) improved professional performance of madrasah principals and teachers; (i) developing democratic leadership in madrasah-policy and decision making, planning, and programming; (j) efforts to increase the fulfillment of supporting facilities for teaching and learning activities; (k) teacher welfare increases; (l) student or 
student-oriented services; (m) a culture of confidence in madrasah management is reduced (Bafadal, 2009).

The philosophy of the quality of the indicators above, in the world of education, is defined as a series of processes for the production of intelligence and human maturity through the educational process with the indicator being the provision of education that satisfies customers (students-parents). Meanwhile, the meaning of educational satisfaction is largely determined by various activities that have appeal because they can answer the various expectations and problems that educational consumers want (Jayakumaran \& Manoharan, 2011).

Meanwhile, according to Amirudin, the characteristics of a madrasah that has implemented MBM can be seen to what extent the madrasah optimizes its performance, the learning process activities for human resource management, and the management of other administrative resources (Siahaan, 2006). MBM is a management model for madrasah where the substance is the implementation of independent education, which includes policies for all elements of society, from planning, implementation, and evaluation. The implementation pattern follows the modern management pattern which has the characteristics of transparency, collegiality, and accountability and is acceptable. When this substance has been implemented properly, a madrasah can be categorized as implementing MBM.

\section{CONCLUSION}

Quality human resources are a mirror of Madrasah-based management $(\mathrm{MBM})$, and MBM is part of quality human resources. This expression has terms and meanings because to make this happen, it is necessary to have expertise and consistency in implementing the established policies. The movement of education reform from centralization to decentralization abroad has been going on for 30 years, since 1960-1990. In Indonesia, constitutional reformation of education began to coincide with the reform era marked by the fall of the New Order in 1998. Education, which had been the matter of the central government, since the enactment of regional autonomy through Law No. Law number 32 of 2004 , then education affairs are left to the regional government. Also, to see the implementation of MBM it consists of three parts, namely; 1) following a strategy; 2) implementation steps, and; 3 ) the indicator.

\section{REFERENCES}

Ahmed, A. (2008). Can Education Affect Pro-Social Behavior? Cops, Economists and Humanists in Social Dilemmas. International Journal of Social Economics. 35(4), 298-307.

Amir, F. (2015). Developing Structure for Management of Quality in Schools : Steps towards Quality Assurance Systems. American Journal of Educational Research, 3(8), 977-981. https:/ / doi.org/10.12691/education-3-8-5 
Arief, A., \& Lubis, A. F. (2020). Inovasi Pendidikan Islam. Yogyakarta: Deepubish. Arikunto, Suharsimi. (1998). Prosedur Penelitian: Suatu Pendekatan Praktik. Jakarta: Rineka Cipta.

Bafadal, Ibrahim. (2009). Manajemen Peningkatan Mutu Sekolah Dasar, dari Sentralisasi Menuju Desentralisasi. Jakarta: Bumi Akasara.

Bustanul, Arifin. (2015). Implementasi Manajemen Berbasis Sekolah dalam Peningkatan Kualitas Pembelajaran di MIN Sumberrejo dan MIM Paremono Kabupaten Magelang. Salatiga: IAIN Salatiga.

Capel, C. M. (2012). Mindlessness/Mindfulness, Classroom Practices and Quality of Early Childhood Education: An Auto-ethnographic and Intrinsic Case Research. International Journal of Quality $\mathcal{E}$ Reliability Management, 29(6), 666-680.

Cut, Aprina. (2016). Pengaruh MBS Terhadap Pengembangan Perpustakaan. Yogyakarta: UIN Sunan Kalijaga.

Danim, Sudarman. (2010). Otonomi Manajemen Sekolah. Bandung: Alfabeta.

Eslianna, E., Lian, B., \& Sari, A. P. (2020). Implementation of School Based Management in Improving the Quality of Education. International Journal of Progressive Sciences and Technologies, 23(1), 316-323.

Gaffar, M. F. (2000). Pembiayaan Pendidikan; Permasalahan dan Kebijaksanaan dalam Perspektif Reformasi Pendidikan Nasional. Bandung: IKIP Bandung.

Iskandar, I. (2019). Prinsip Komunikasi Al-Qur'an dalam Menghadapi Era Media Baru. Jurnal Al-Fanar, 2(1), 55-74. https:/ / doi.org/10.33511/alfanar.v2n1.55-74

Jayakumaran, M., \& Manoharan, C. (2011). Review Article Total Quality Management in Education. International Journal of Current Research, 3(3), 149-153.

Lee, D. H. L., \& Chiu, C. S. (2017). “School banding”: Principals' Perspectives of Teacher Professional Development in The School-based Management Context. Journal of Educational Administration, 55(6), 686-701. https://doi.org/10.1108/JEA-02-2017-0018.

Muzayanah, Umi. (2014). Manajemen Madrasah sebagai Media Strategis Pendidikan Karakter. Jurnal Analisa, 21(2), 279-289

Myende, P. E., Samuel, M. A., \& Pillay, A. (2018). Novice Rural Principals ' Successful Leadership Practices in Financial Management: Multiple Accountabilities. South African Journal of Education, 38(2), 1-11.

Naisbitt, John. (1982). Megatrends: Ten New Directions Transforming Our Lives. New York: Warner Books.

Rofiq, A. (2017). Wealth Management Strategi Pengelolaan Asset:Transparansi, Akuntabilitas, Efektifitas, Efisiensi. Al-Tanzim: Jurnal Manajemen Pendidikan Islam, 1(1), 67-75.

Sholekah, F. F., \& Mahmudah, F. N. (2020). The Management Strategy of Headmaster in Efforts to Increase Self Awareness of School Residents of the Importance Environment. Journal of Educational Administration Research and Review, 4(1), 62-67.

Tardian, A. (2019). Manajemen Strategik Mutu Sekolah: Studi Kasus di SD A1Irsyad Al Islamiyyah 02 Purwokerto. Jurnal Kependidikan, 7(2), 192-203. 
Tilaar, HAR. (2002). Membenahi Pendidikan Nasional. Jakarta: PT Rineka Cipta.

Umar, B. B., Krauss, S. E., Samah, A. A., \& Hamid, J. A. (2017). Youth Voice in Nigerian School-based Management Committees. International Journal of Education \& Literacy Studies, 5(1), 86-93. 